\title{
Optimalisasi Sistem Mikrogrid Hibrida Berbasis Jarak Pagar menggunakan HOMER
}

\author{
IBRAHIM, DANI RUSIRAWAN
}

\author{
Magister Teknik Mesin Institut Teknologi Nasional (ITENAS) Bandung \\ Email: ibrahimst@live.com
}

Received 24 Januari 2019 | Revised 6 Februari 2019 | Accepted 24 Maret 2019

\begin{abstract}
ABSTRAK
Penggunaan genset diesel minyak solar untuk kelistrikan di pulau Medang terkendala dengan mahal dan tingginya biaya pengadaan minyak solar. Biomassa jarak pagar yang ada di pulau Medang potensial untuk dimanfaatkan sebagai sumber daya alam (SDA) lokal, untuk menggantikan minyak solar sebagai bahan bakar genset. Bahan bakar yang dapat dihasilkan dari buah jarak pagar terdiri dari straight vegetable oil (SVO), biogas dan synthetic gas (syngas). Berdasarkan data sekunder, 1 ha kebun jarak pagar dapat menghasilkan listrik 19.425 kWh/tahun menggunakan genset diesel berbahan bakar SVO ditambah 6.475 $\mathrm{kWh} /$ tahun menggunakan genset biogas. Dalam penelitian ini, optimalisasi sistem mikrogrid hibrida berbasis jarak pagar sudah dilakukan. Kondisi optimal untuk beban rata-rata $4.000 \mathrm{kWh} / \mathrm{hari}$ terdiri dari $1 \times 360 \mathrm{~kW}$ genset SVO $+1 X 360 \mathrm{~kW}$ genset Biogas + Baterai $300 \mathrm{kWh}$ + inverter-rectifier $300 \mathrm{~kW}$. Hasil evaluasi memperlihatkan untuk operasi 25 tahun, sistem mikrogrid hibrida berbasis biomassa jarak pagar membutuhkan net present cost (NPC) sebesar $\$ 7.750 .000$ dan memberikan cost of energy (COE) \$0,368/kWh.
\end{abstract}

Kata kunci: genset, bioenergi, SVO, biogas, listrik

\begin{abstract}
Utilization of diesel oil for diesel generators in the Medang island is constrained by high costs of diesel oil. The jatropha (type of biomass) in the Medang island can be used as a local natural resource (SDA), in substituting of diesel oil as a generator fuel. The type of fuel whics is produced by jatropha consist of straight vegatable oil (SVO), biogas and synthetic gas (syngas). Based on secondary data, it is found that 1 ha of Jatropha equal by produces electricity 19.425 $\mathrm{kWh} /$ year using an SVO diesel generator set and $6.475 \mathrm{kWh} /$ year using biogas generator set. In this study, optimization of the hybrid microgrid system was carried out. The optimal conditions for an average 4,000 kWh/day of load is consisting of $1 X 360 \mathrm{~kW}$ SVO generator $+1 X 360 \mathrm{~kW}$ Biogas generator $+300 \mathrm{kWh}$ $+300 \mathrm{~kW}$ rectifier inverter. Evaluation results showed that for 25-year operation, the hybrid microgrid jatophra bases system requires of NPC of $\$ 7,750,000$ and yield the COE of $\$ 0.368 / \mathrm{kWh}$.
\end{abstract}

Keywords: genset, bioenergy, SVO, biogas, electricity 


\section{PENDAHULUAN}

Di pulau-pulau terpencil, penggunaan genset diesel minyak solar untuk melayani kebutuhan listrik terkendala dengan mahalnya biaya pengadaan energi primer. Salah satu solusi yang dapat ditawarkan untuk mengatasi kendala tersebut adalah dengan mengembangkan pembangkit listrik berbasis energi terbarukan (ET), yang menerapkan konsep sistem microgrid (mikrogrid) dan hybrid (hibrida). Microgrid adalah jaringan kecil yang lengkap dengan pembangkit (bisa terbarukan maupun konvensional), beban, penyimpan energi, dan jaringan distribusinya serta bisa berdiri sendiri atau tersambung ke jaringan besar (macrogrid). Sementara itu, pembangkit hibrida tidak berbeda dengan pembangkit tunggal terpusat (konvensional). Bedanya hanya terletak pada sumber energi yang digunakan. Kombinasi konsep mikrogrid dan hibrida diharapkan dapat memenuhi kebutuhan standar sistem kelistrikan berpola islanding (Irawati \& Zuhaidi, 2012).

Penelitian-penelitian yang sejalan dengan topik ini adalah: Economic Study of Hibrid Power System in Selayar Island (Yunus, 2013), Model Pembangkitan Listrik Hibrid PV-Genset Berbasis Komunal di Pulau Karimun Jawa (Gunawan, 2016), Design and Optimization of Hybrid Power Plant in Household Scales using Homer Models (Ibrahim \& Rusirawan, 2017).

Berdasarkan hasil wawancara dengan warga masyarakat, diketahui bahwa kondisi penyediaan listrik di Pulau Medang masih kurang dari kebutuhan totalnya. Saat ini, penyediaan listrik di Pulau Medang dilayani menggunakan sistem Pembangkit Listrik Tenaga Diesel (PLTD) berbahan bakar minyak solar. Operasi sistem pembangkit hanya mampu dilakukan untuk 12 jam per hari, dari pukul 18.00 sampai pukul 06.00. Kendala utama adalah sulit dan mahalnya distribusi bahan bakar minyak solar ke lokasi (PLN Sumbawa, 2016).

Potensi sumber daya energi lokal yang ada dan dapat dimanfaatkan di pulau Medang adalah biomassa jarak pagar berupa minyak biji dan biogas bungkil minyak. Tujuan yang diharapkan dari penelitian ini adalah menghasilkan rekomendasi sistem pembangkit listrik hibrida (PLH) berbasis bahan bakar minyak dan biogas jarak pagar yang optimal menggunakan HOMER (Hybrid Optimization of Multiple Energy Resources).

\section{METODOLOGI PENELITIAN}

Secara geografis, Pulau Medang terletak di sebelah Utara Pulau Sumbawa pada $08^{\circ} 008^{\prime 2} 23^{\prime \prime}$ LS dan $117^{\circ} 023^{\prime} 16^{\prime \prime}$ BT. Secara administratif berada di Kecamatan Labuhan Badas, Kabupaten Sumbawa, Nusa Tenggara Barat, seperti pada Gambar 1 (BPS Kabupaten Sumbawa, 2016).
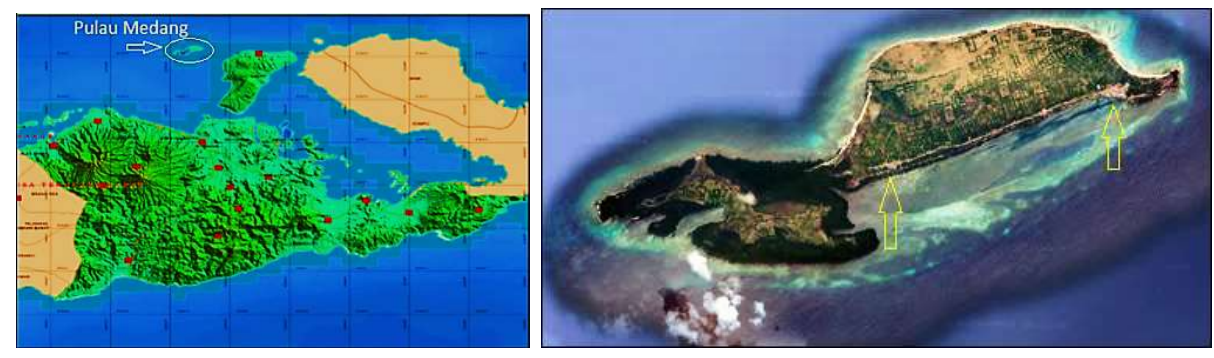

Gambar 1. Posisi Geografis (Google Earth, 2018) 
Pulau Medang memiliki panjang $9 \mathrm{~km}$ dan luas total 27,65 km² serta $23 \mathrm{~km}^{2}$ (2.300 ha) diantaranya adalah lahan kosong untuk berkebun. Pulau Medang terdiri dari 2 desa, yaitu:

1) Desa Bajo Medang (8,65 km2) dihuni oleh 1.509 jiwa dalam $449 \mathrm{KK}$

2) Desa Bugis Medang (19,0 km2) dihuni oleh 1.038 jiwa dalam 364 KK.

Masyarakat Pulau Medang menikmati listrik sejak tahun 2000 setelah PT. PLN Wilayah Sumbawa berhasil membangun PLTD Bugis Medang berbahan bakar minyak (BBM) solar. PLTD Bugis Medang berkapasitas terpasang $360 \mathrm{~kW}$ terdiri dari 35 genset diesel dengan jumlah pelanggan sebanyak 456 rumah atau KK dan berbeban puncak sebesar 115 kW (PLN Sumbawa, 2016) dan (Direktorat PPK, 2012). Baseline beban kelistrikan perumahan sederhana di desa seperti di Pulau Medang memiliki faktor beban 0,1-0,3 (Wiyono \& Tatipikalawan, 2015) dan faktor kebutuhan $50-75 \%$ (Nababan, 2015) seperti yang ditampilkan pada Gambar 2.

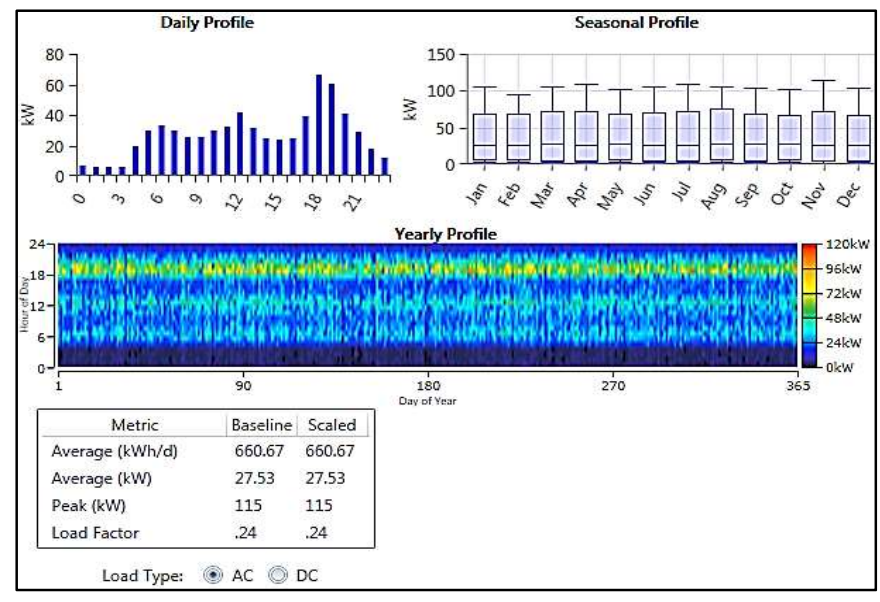

\section{Gambar 2. Baseline Beban Kelistrikan di Pulau Medang}

Dalam kajian ini, konsep pembangkit listrik hibrida dan mikrogrid berbasis bahan bakar minyak dan biogas jarak pagar akan dievaluasi sebagai alternatif mengatasi persoalan kelistrikan di Pulau Medang menggunakan HOMER Pro Edition 3.11.6. HOMER merupakan salah satu tool populer yang biasa digunakan untuk simulasi dalam perencanaan, analisis dan optimisasi model serta mempermudah evaluasi desain suatu sistem pembangkit listrik mikrogrid maupun hibrida (HOMER Energy, 2015). Pada prinsipnya HOMER bekerja berdasarkan tiga langkah utama, yaitu simulasi, optimisasi dan analisis sensitifitas. HOMER dilengkapi dengan fitur untuk melakukan hal berikut ini:

1) variasi load, component, resources dan system, stand-alone atau grid-connected.

2) simulasi operasi sistem dengan energy balance untuk 8,760 jam per tahun.

3) menentukan run and off generator serta sekaligus dapat mengatur dan menentukan baterai di-isi atau di-kosongkan, manakala sistem terinterkoneksi dengan jaringan besar (on-grid) dan atau menggunakan baterai serta genset.

Dalam evaluasi, kriteria optimalisasi sistem didesain harus memenuhi ketentuan tanpa capacity shortage, minimum excess electricity, minimum runtime, mean electrical efficiency yang optimal, capacity factor yang optimal dan menghasilkan emisi GRK yang minimal serta semaksimal mungkin dapat mensubstitusi pemakaian bahan bakar minyak solar (MS). Adapun syarat optimalisasi operasi pembangkit adalah operasi dengan nilai NPC (net present cost) dan COE (cost of energy) yang minimal. 
Metodologi yang digunakan dalam penelitian ini terdiri dari:

\section{1) Identifikasi Masalah}

Identifikasi masalah dilakukan melalui studi literatur untuk mendapatkan informasi penelitian terdahulu serta untuk mendapatkan informasi yang seimbang. Dalam kajian ini, komponen energetik tanaman jarak pagar yang digunakan hanya dari bagian bijinya saja. Dimana, minyak jarak pagar murni (straight vegetable oil atau SVO) diperoleh dari proses pemurnian minyak melalui degumming dan netralizing. Sementara itu, biogas diperoleh dari proses fermentasi anaerobik bungkil minyak dalam reaktor pencernaan (digester). Jalur pemanfaatan biomassa biji jarak pagar untuk menghasilkan listrik terlihat pada Gambar 3.

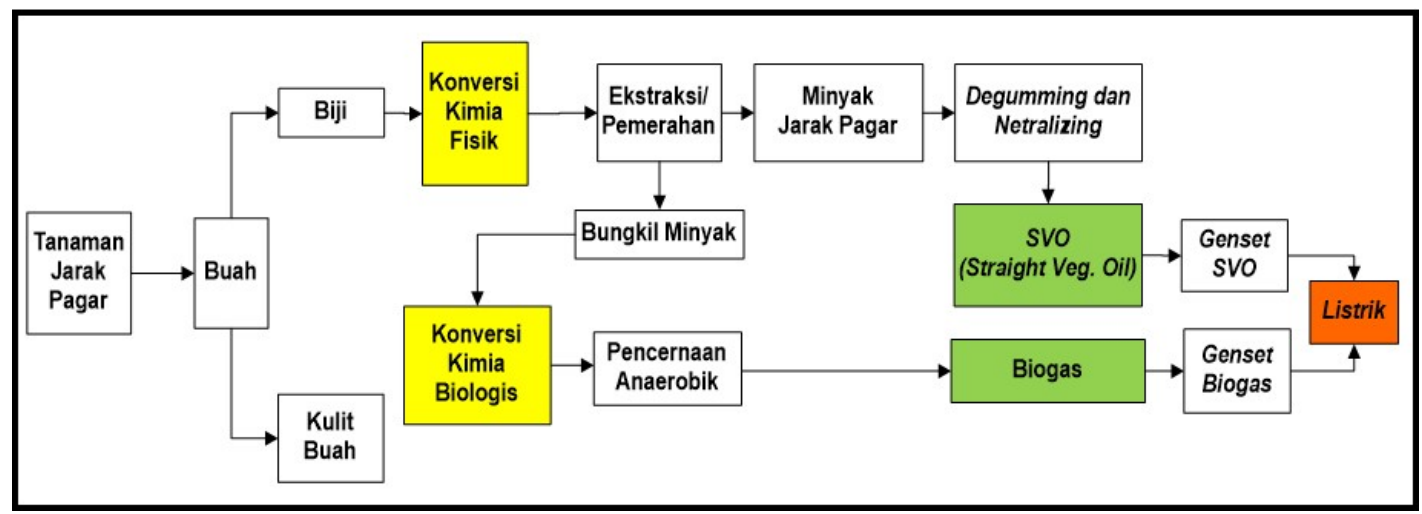

Gambar 3. Konsep Pemanfaatan Bioenergi Jarak Pagar dalam Penelitian

\section{2) Pengumpulan Data}

Metoda pengumpulan data dilakukan melalui wawancara dan studi literatur. Wawancara dilakukan untuk mengumpulkan informasi kondisi masyarakat dan penggunaan listrik di lokasi. Studi literatur dilakukan untuk mendapatkan data primer terkait dengan analisis sistem PLH menggunakan HOMER. Data-data yang dibutuhkan terdiri dari:

a) Kondisi beban listrik, yaitu: jumlah pelanggan, profil, jenis dan rating beban;

b) Populasi dan pertumbuhan penduduk, ekonomi dan kebutuhan listrik;

c) Spesifikasi standar dan harga komponen, yaitu: harga genset dan harga controller,

d) Harga buah dan biji jarak pagar;

e) Konversi energi biomassa berbasis tanaman jarak pagar, yaitu: SVO dan biogas;

f) Harga terkait perbankan, yaitu discount rate dan inflation rate.

\section{3) Perancangan Sistem Pembangkit Listrik Hibrida}

Perancangan sistem PLH disesuaikan dengan kebutuhan listrik di lokasi dengan waktu operasi untuk 24 jam sehari dalam 7 hari setiap minggu. Sistem PLH ini terdiri dari 1 unit genset diesel SVO $360 \mathrm{~kW}$ dan 1 unit genset biogas $360 \mathrm{~kW}$. Spesifikasi teknis genset SVO memiliki nilai capacity factor sebesar $70-100 \%$ dan efisiensi sebesar $35 \%$ serta specific fuel consumption (sfc) sebesar 0,30 liter/kWh. Sementara itu, spesifikasi teknis genset Biogas memiliki nilai capacity factor sebesar $60 \%-100 \%$ dan efisiensi sebesar $30 \%$ serta specific fuel consumption (sfc) sebesar 2,7 kg/kWh. 
Penetapan kapasitas pembangkit dan proyeksi permintaan listrik dirancang sampai 25 tahun ke depan. Targetnya adalah untuk memenuhi listrik sebesar $1.293 \mathrm{kWh} / \mathrm{kapita} / \mathrm{tahun}$ pada tahun 2019 dan 2.500 kWh/kapita/tahun pada tahun 2025 (Kementerian ESDM, 2016). Kondisi ini untuk memenuhi tingkat konsumsi energi standar masyarakat sejahtera secara berkelanjutan sekitar 700-940 kgoe/kapita/tahun atau setara 1-1,33 kW/kapita/tahun (Goldemberg, 1990) dan (Suárez, 1995).

Sesuai dengan tingkat konsumsi energi ini, maka diperkirakan total kebutuhan listrik di Pulau Medang mencapai 3.293.271 kWh/tahun. Berdasarkan asumsi tersebut, maka kapasitas pembangkit listrik yang dibutuhkan sesuai baseline beban kelistrikan exsisting dan pertumbuhan beban dapat ditampilkan seperti pada Tabel 1.

Tabel 1. Kapasitas Pembangkit Listrik

\begin{tabular}{|l|c|r|}
\hline \multirow{2}{*}{ Pembangkit Listrik } & \multirow{2}{*}{ Bahan Bakar } & \multicolumn{2}{|c|}{ Kapasitas } \\
\cline { 3 - 3 } & & (kW) \\
\hline PLTD-SVO & SVO & 360 \\
\hline PLTGas-Biogas & Biogas & 360 \\
\hline
\end{tabular}

Skema pelaksanaan penelitian ini diperlihatkan pada Gambar 4 dan konsep sistem PLH dalam penelitian ini diperlihatkan pada Gambar 5.

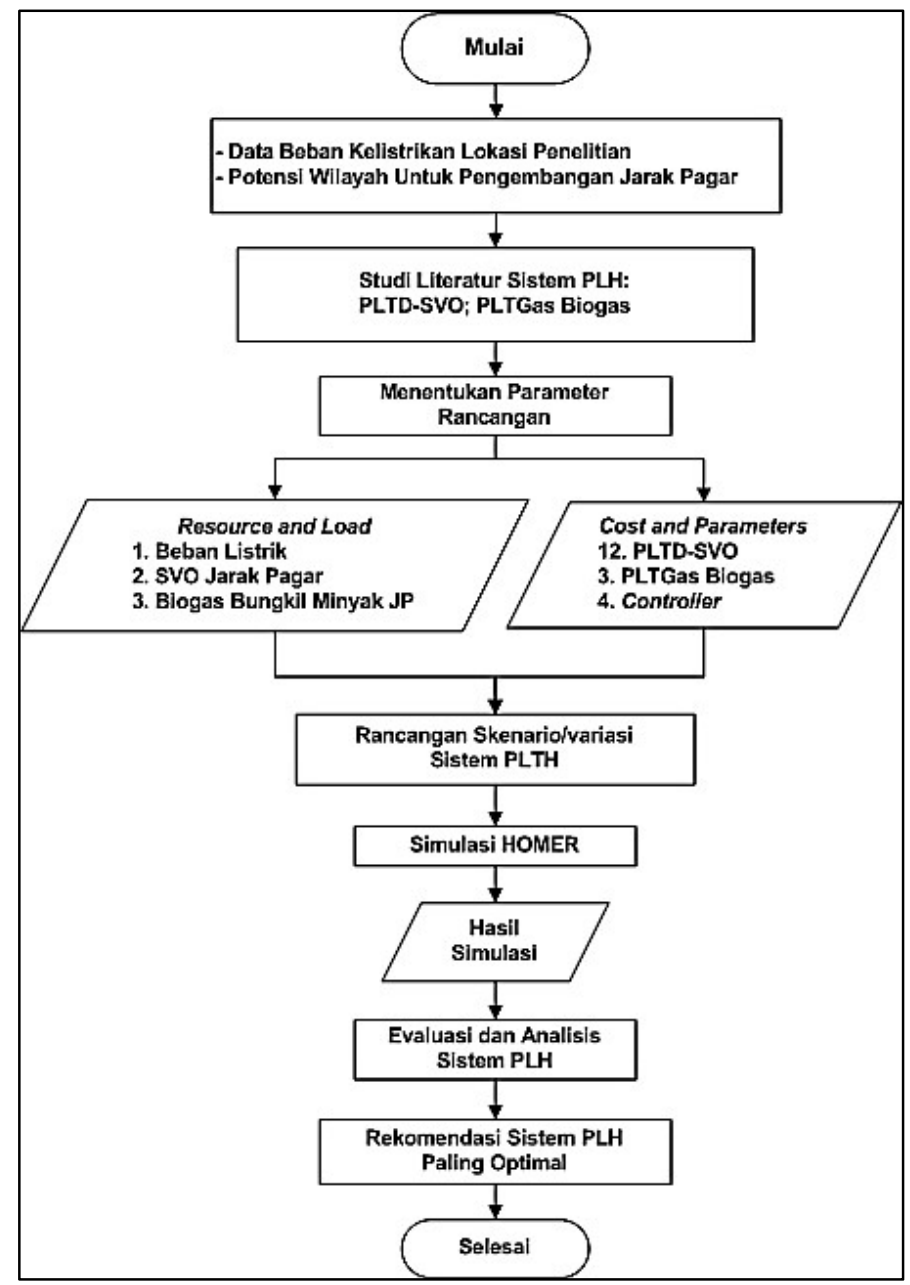

Gambar 4. Skema Pelaksanaan Penelitian 


\section{4) Perancangan Simulasi}

Aplikasi dan rating operasi pembangkit listrik sebagai prime mover didesain sesuai standar genset. Genset continuous/prime rated power maupun genset emergency standby power memiliki kemampuan yang sama dalam melayani beban sampai $70 \%-100 \%$ nilai kapasitas teknisnya. Genset continuous mampu bekerja 8.760 jam per tahun untuk kondisi beban bervariasi (ISO 3046, AS 2789, DIN 6271 dan BS 5514). Pada keadaan darurat diizinkan beroperasi overload $10 \%$ selama maksimum 1 jam setiap 12 jam dan maksimum 25 jam per tahun (AS 4509.2-2005). Untuk genset emergency standby power, kerjanya dibatasi 1-2 jam per operasi dan maksimum 200 jam per tahun.

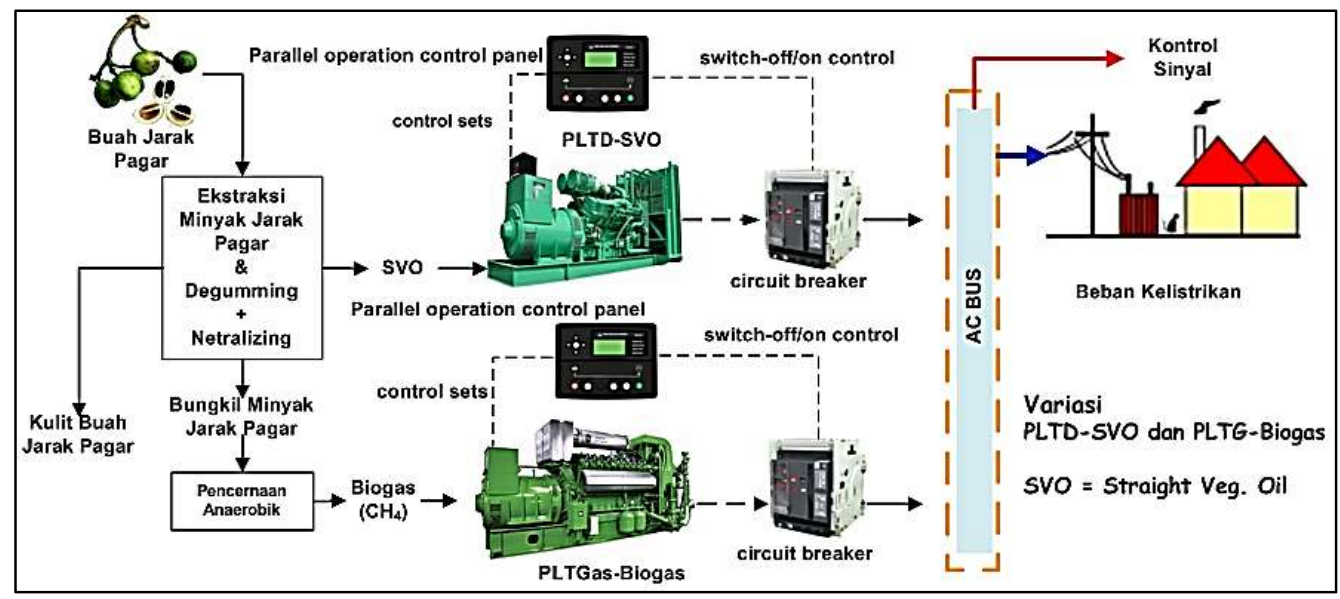

Gambar 5. Konsep PLH Berbasis Biomassa Jarak Pagar

Tabel 2. Data Spesifikasi Genset

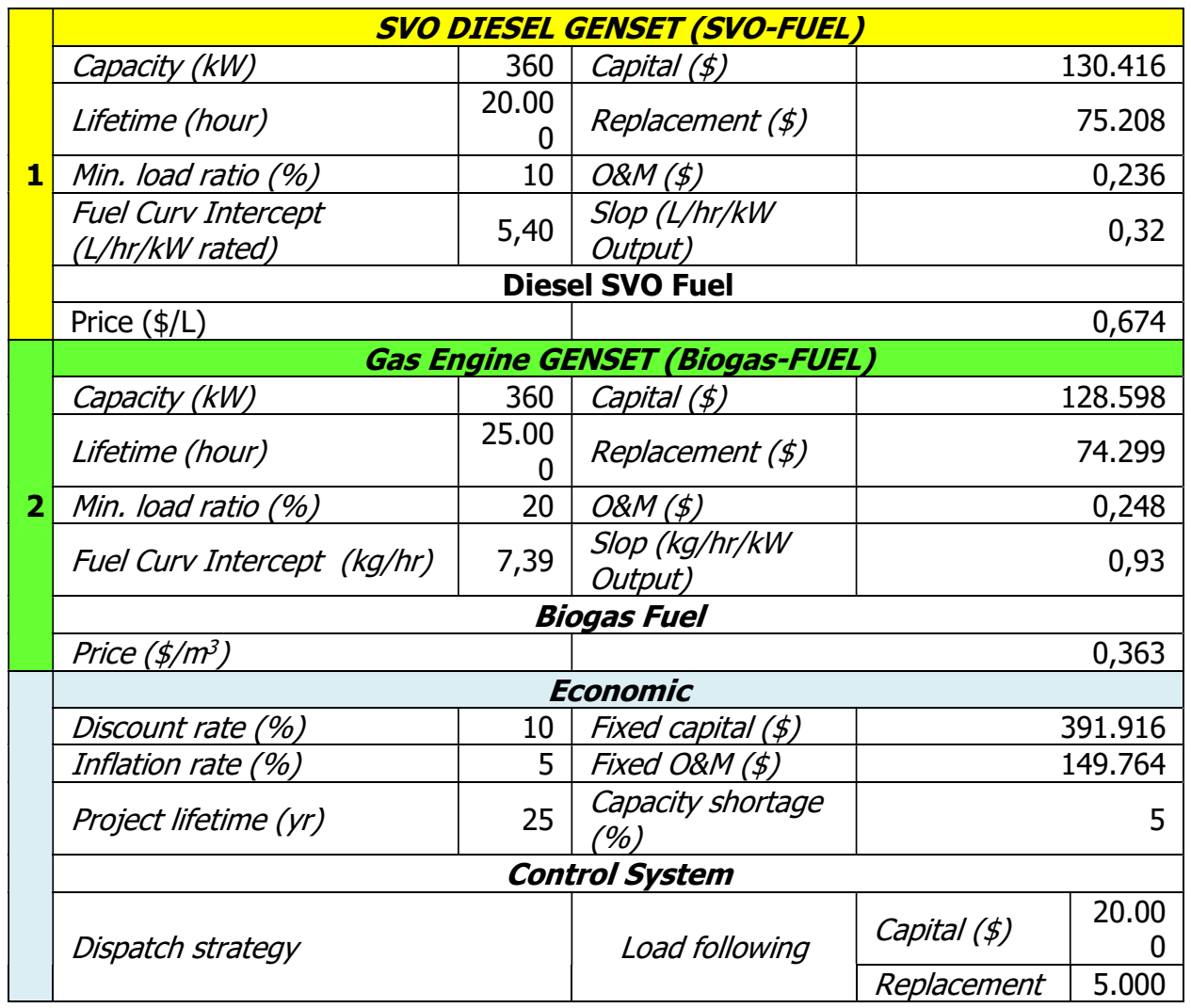




\begin{tabular}{|l|l|l|r|}
\hline \multirow{5}{*}{} & & $(\$)$ & \\
\cline { 3 - 4 } & & O\&M $(\$ / y r)$ & 100 \\
\cline { 3 - 4 } & \multirow{4}{*}{ Generator Order } & Capital $(\$)$ & 25.00 \\
\cline { 3 - 4 } & & $\begin{array}{l}\text { Replacement } \\
(\$)\end{array}$ & 6250 \\
\cline { 3 - 4 } & & O\&M $(\$ / y r)$ & 200 \\
\hline
\end{tabular}

Desain site specific dalam kajian ini ditentukan include in all systems berdasarkan standar operasi genset. Dimana, waktu operasi dan minimum runtime genset (biogas maupun SVO) dioptimalisasi oleh simulasi sesuai rating genset continuous yang dipilih. Sensitivitas average load scale didesain antara 660,67 kW/hari (beban excisting) sampai $4.000 \mathrm{~kW} / \mathrm{hari}$ (kebutuhan total). Load ratio genset biogas didesain $50-100 \%$ dan load ratio genset SVO didesain $30-85 \%$. Genset biogas didesain sebagai genset utama dan genset SVO didesain sebagai genset pendukung pada saat beban puncak. Data spesifikasi genset diperlihatkan Tabel 2 dan alur simulasi ditunjukkan pada Gambar 6.

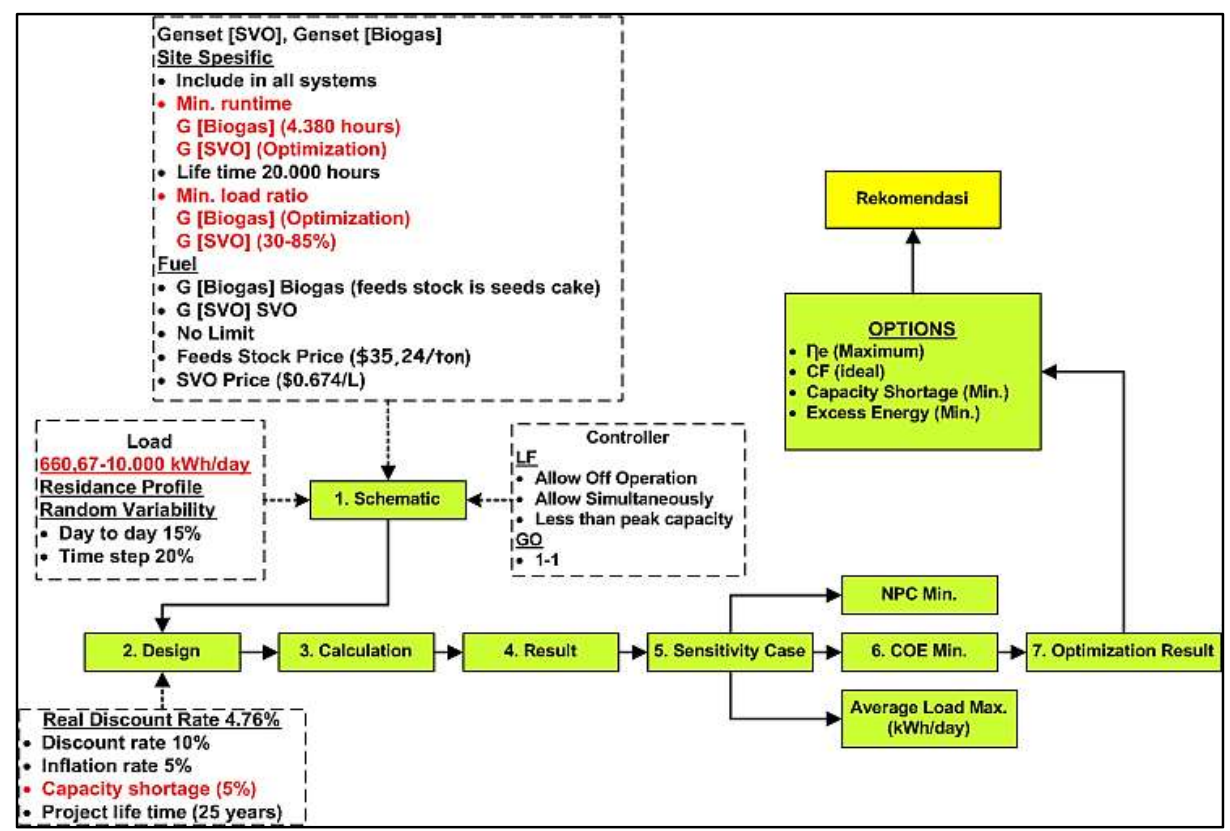

Gambar 6. Proses Simulasi Operasi Sistem PLH Genset Biogas+Genset SVO

\section{HASIL DAN DISKUSI}

Simulasi menghasilkan average load scale ideal untuk operasi sistem PLH sebesar 4.000 $\mathrm{kWh} /$ hari (1.460.000 kWh/tahun), dengan beban rata-rata 166,67 kW dan beban puncak 696,27 kW serta faktor beban 0,24. Gambar 7 menampilkan arsitektur sistem PLH dan data spesifikasi sistem PLH hasil simulasi ditunjukkan pada Tabel 3. 


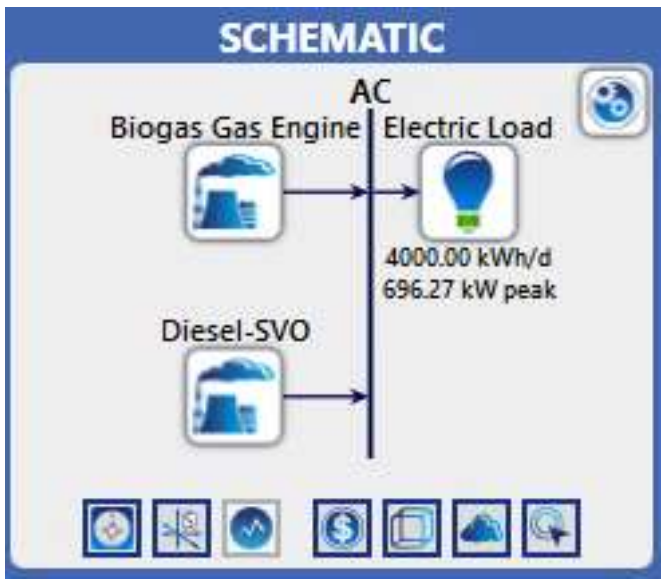

Gambar 7. Arsitektur Sistem PLH

Tabel 3. Data Spesifikasi Sistem PLH (PLTD SVO+PLTG Biogas) Hasil Simulasi

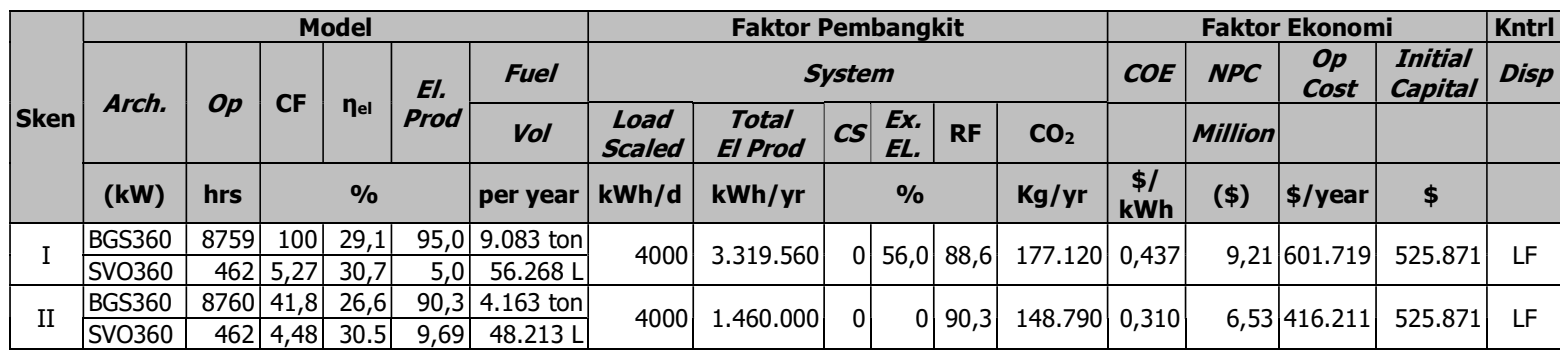

\subsection{Faktor Teknis Sistem PLH genset Biogas+genset SVO Berdasarkan Simulasi}

\section{Skenario I}

Genset Biogas beroperasi dengan capacity factor $100 \%$ menghasilkan mean electrical efficiency $29,1 \%$ dan specific fuel consumption $0,951 \mathrm{~kg} / \mathrm{kWh}$. Sistem ini menghasilkan electrical production sebesar $3.153 .240 \mathrm{kWh} /$ tahun dan membutuhkan bahan bakar sebesar 9.083 ton/tahun untuk beroperasi 8.759 jam/tahun, dengan umur operasi 2,28 tahun. Sementara itu, genset SVO beroperasi dengan capacity factor $5.27 \%$ menghasilkan mean electrical efficiency $30,7 \%$ serta specific fuel consumption sebesar 0,338 liter/kWh. Sistem ini menghasilkan electrical production sebesar $166.320 \mathrm{kWh} /$ tahun dan membutuhkan bahan bakar sebesar 56.268 liter/tahun untuk beroperasi 462 jam/tahun, dengan umur operasi 43,3 tahun.

Operasi skenario I ini menghasilkan total produksi listrik sebesar 3.319.560 kWh/tahun yang digunakan untuk $100 \%$ beban listrik AC dengan excess electricity sebesar $56 \%$ (1.859.560 kWh/tahun). Produksi listrik dari genset Biogas sebesar 95\% dan sisanya 5\% diperoleh dari genset SVO, pada saat beban puncak saja.

\section{Skenario II}

Genset Biogas pada skenario ini beroperasi dengan capacity factor $41,8 \%$ menghasilkan mean electrical efficiency $26,6 \%$ dan specific fuel consumption $1,04 \mathrm{~kg} / \mathrm{kWh}$. Sistem ini menghasilkan electrical production sebesar $1.318 .594 \mathrm{kWh} /$ tahun dan membutuhkan bahan bakar sebesar 4.163 ton/tahun untuk beroperasi 8.760 jam/tahun dengan umur operasi 2,85 tahun. Sementara itu, genset SVO beroperasi dengan capacity factor $4,48 \%$ menghasilkan mean electrical efficiency $30,5 \%$ serta specific fuel consumption sebesar 0,341 liter/kWh. Sistem ini menghasilkan electrical production sebesar $141.406 \mathrm{kWh} / \mathrm{tahun}$ dan membutuhkan 
bahan bakar sebesar 48.213 liter/tahun untuk beroperasi 462 jam/tahun dengan umur operasi 43,3 tahun.

Operasi skenario II ini menghasilkan total produksi listrik sebesar $1.460 .000 \mathrm{kWh} /$ tahun yang digunakan untuk $100 \%$ beban listrik AC secara proporsional tanpa capacity shortage dan tanpa excess electricity. Genset Biogas menghasilkan listrik 90,3\% dan genset SVO menghasilkan listrik 9,69\% pada saat beban puncak saja.

\subsection{Faktor Ekonomi Sistem PLH genset Biogas+genset SVO}

Dalam evaluasi keekonomian, biaya investasi peralatan dan bahan baku untuk produksi SVO dan untuk produksi biogas diperhitungkan dengan asumsi SVO dan biogas diperoleh dari sumber daya alam lokal, yaitu biji jarak pagar. Dalam hal ini, total system fixed captal cost untuk produksi SVO dan untuk produksi biogas sebesar $\$ 246.857$ dan total system fixed O\&M cost untuk produksi SVO dan untuk produksi biogas sebesar $\$ 211,641$.

\section{Skenario I}

Operasi skenario I ini berlangsung selama 25 tahun menghasilkan cost of energy (COE) sebesar $\$ 0,437 / \mathrm{kWh}$ dan total net present cost (NPC) $\$ 9.210 .000$. Biaya O\&M sebesar $34 \%$ dan biaya bahan bakar mencapai $56 \%$, terdiri dari $6 \%$ biaya SVO dan $50 \%$ biaya biogas.

\section{Skenario II}

Operasi skenario II ini berlangsung selama 25 tahun menghasilkan cost of energy (COE) sebesar $\$ 0,310 / \mathrm{kWh}$ dan total net present cost (NPC) $\$ 6.530 .000$. Biaya O\&M sebesar $47 \%$ dan biaya bahan bakar mencapai $40 \%$, terdiri dari: biaya SVO $7 \%$ dan biaya biogas $33 \%$.

\subsection{Faktor GRK Sistem PLH genset SVO+genset Biogas Hasil Simulasi}

\section{Skenario I}

Operasi ini menghasilkan renewable fraction sebesar $88,6 \%$ dan emisi $\mathrm{CO}_{2}$ sebesar 0,053 $\mathrm{kg} / \mathrm{kWh}$ dari total produksi listrik $3.319 .560 \mathrm{kWh} /$ tahun dan total $\mathrm{CO}_{2}$ sebesar 177.120 $\mathrm{kg} /$ tahun.

\section{Skenario II}

Operasi ini menghasilkan renewable fraction sebesar 90,3\% dan emisi $\mathrm{CO}_{2}$ sebesar 0,102 $\mathrm{kg} / \mathrm{kWh}$ dari total produksi listrik $1.460 .000 \mathrm{kWh} /$ tahun dan total $\mathrm{CO}_{2}$ sebesar 148.790 $\mathrm{kg} /$ tahun.

\subsection{Analisis Hasil Simulasi Operasi Skenario I dan II}

\subsubsection{Analisis Faktor Teknis}

Pada skenario I, genset Biogas beroperasi dengan capacity factor $100 \%$ menghasilkan mean electrical efficiency $\left(\eta_{e}\right)$ lebih rendah $0,9 \%$ dan specific fuel consumption ( $s f c$ ) lebih rendah $1,75 \mathrm{~kg} / \mathrm{kWh}$ dari standarnya. Sementara itu, genset SVO beroperasi dengan capacity factor $5,27 \%$ menghasilkan mean electrical efficiency $\left(\eta_{e}\right)$ lebih rendah $4,3 \%$ dan specific fuel consumption (sfc) lebih tinggi (boros) 0,038 liter/kWh dari standarnya.

Pada skenario II, genset Biogas beroperasi dengan capacity factor $41,8 \%$ menghasilkan mean electrical efficiency $\left(\eta_{e}\right)$ lebih rendah $3,4 \%$ dan specific fuel consumption (sfc) lebih rendah (irit) $1,66 \mathrm{~kg} / \mathrm{kWh}$ dari standarnya. Sementara itu, genset SVO ini beroperasi dengan capacity factor $4,48 \%$ menghasilkan mean electrical efficiency $\left(\eta_{e}\right)$ lebih rendah $4,5 \%$ dan specific fuel consumption (sfc) lebih tinggi (boros) 0,051 liter/kWh dari standarnya. 
Operasi sistem PLH skenario I ini menghasilkan excess electricity sebesar $56 \%$ dari total produksi listrik. Sementara itu untuk skenario II, genset biogas beroperasi pada capacity factor lebih rendah $58,2 \%$ dari standar operasinya dan tanpa excess electricity. Data spesifikasi faktor teknis hasil simulasi skenario I dan II diperlihatkan pada Tabel 4.

Secara teoritik, operasi genset biogas skenario I menghasilkan $\eta_{\text {th }} 28,7 \%$ dan operasi genset SVO menghasilkan $\eta_{\text {th }} 30 \%$. Operasi genset biogas skenario II menghasilkan $\eta_{\text {th }} 27 \%$ dan operasi genset SVO menghasilkan $\eta_{\text {th }}$ 30,2\%. Efisiensi termal $\left(\eta_{\text {th }}\right)$ operasi genset Biogas skenario I lebih tinggi $2,5 \%$ dari hasil skenario II dan efisiensi termal $\left(\eta_{t h}\right)$ operasi genset SVO skenario I lebih tinggi 0,3\% dari hasil skenario II.

Tabel 4. Data spesifikasi (Faktor Teknis) Hasil Simulasi

\begin{tabular}{|c|c|c|c|c|c|c|c|c|c|}
\hline \multirow{2}{*}{$\begin{array}{l}\text { Sk } \\
\text { en }\end{array}$} & \multirow{2}{*}{$\begin{array}{c}\text { Sistem } \\
\text { Pembangkit }\end{array}$} & Load & $\begin{array}{l}\text { Cap. } \\
\text { Factor }\end{array}$ & $\eta_{t h}$ & $\eta e l$ & \multirow{2}{*}{$\begin{array}{c}\begin{array}{c}\text { Elect } \\
\text { Prod }\end{array} \\
\text { kWh/thn }\end{array}$} & \multirow{2}{*}{$\begin{array}{c}\begin{array}{c}\text { Fuel } \\
\text { Consu } \\
\text { mp }\end{array} \\
\text { tahun }^{-1}\end{array}$} & \multirow{2}{*}{$\begin{array}{c}S F C \\
k W h^{-1} \\
\end{array}$} & \multirow{2}{*}{$\begin{array}{c}\text { Excess } \\
\text { Electr. } \\
\%\end{array}$} \\
\hline & & $\begin{array}{c}\text { kWh/ } \\
\text { hari }\end{array}$ & \multicolumn{3}{|c|}{$\%$} & & & & \\
\hline \multirow{2}{*}{ I } & Biogas (360 kW) & \multirow{2}{*}{4000} & 100 & $\begin{array}{r}28, \\
7\end{array}$ & $\begin{array}{r}29, \\
1 \\
\end{array}$ & 3.153 .240 & $\begin{array}{r}9.083 \\
\text { ton }\end{array}$ & $\begin{array}{r}0,951 \\
\mathrm{~kg}\end{array}$ & \multirow[b]{2}{*}{56,0} \\
\hline & SVO (360kW) & & 5,27 & 30 & $\begin{array}{r}30, \\
7\end{array}$ & 166.320 & $\begin{array}{r}56.268 \\
\text { liter }\end{array}$ & $\begin{array}{r}0,338 \\
\text { liter }\end{array}$ & \\
\hline \multirow[b]{2}{*}{ II } & Biogas (360 kW) & \multirow{2}{*}{4000} & 41,8 & 27 & $\begin{array}{r}26, \\
6\end{array}$ & 1.318 .594 & $\begin{array}{r}4.163 \\
\text { ton }\end{array}$ & $\begin{array}{r}1,04 \\
\mathrm{~kg}\end{array}$ & \multirow{2}{*}{0} \\
\hline & SVO (360kW) & & 4,48 & $\begin{array}{r}30, \\
2\end{array}$ & $\begin{array}{r}30 . \\
5\end{array}$ & 141.406 & $\begin{array}{r}48.213 \\
\text { liter }\end{array}$ & $\begin{array}{r}0,341 \\
\text { liter }\end{array}$ & \\
\hline
\end{tabular}

Secara teknis, operasi genset biogas maupun genset SVO skenario I menghasilkan prestasi yang lebih ideal dari skenario II. Operasi genset biogas maupun genset SVO skenario I menghasilkan produksi listrik yang lebih besar dari pada skenario II. Pada kasus ini, genset biogas dan genset SVO pada skenario I beroperasi menghasilkan listrik lebih tinggi dari sistem PLH lainnya. Kendala operasi sistem PLH pada skenario I adalah terjadinya kerugian energi berupa excess electricity sebesar $56 \%$ yang terjadi pada waktu-waktu operasi beban rendah (dasar). Solusi untuk mengatasinya adalah melakukan penambahan beban kelistrikan pada waktu-waktu operasi selain waktu beban puncak. Penambahan beban kelistrikan dapat berupa pemasangan sistem energy storage maupun pemanfaatan energi listrik untuk kegiatan produktif (industri rumah tangga).

\subsubsection{Analisis Faktor Ekonomi}

Standar normal harga pokok produksi (HPP) pembangkit listrik yang menjadi acuan adalah sebesar $\$ 0,27 / \mathrm{kWh}$ dengan perincian untuk biaya bahan bakar $77 \%(\$ 0,21)$, biaya O\&M sebesar 9\% $(\$ 0,02)$, biaya instalasi $2 \%(\$ 0,01)$ dan biaya kapital $12 \%(\$ 0,03)$ (Paudel, 2013). Standar harga produksi listrik maksimal mengacu pada HPP pembangkit listrik berbahan bakar minyak di Indonesia Timur dan daerah-daerah terpencil sebesar $\$ 0,48 / \mathrm{kWh}$ (Rp. 6.691/kWh) (ESDM, 2017). Tabel 5 menampilkan faktor ekonomi hasil simulasi. 
Tabel 5. Data Spesifikasi (Faktor Ekonomi) Hasil Simulasi

\begin{tabular}{|c|c|c|c|c|c|c|c|}
\hline \multirow{2}{*}{ Skenario } & \multirow{2}{*}{$\begin{array}{c}\text { Sistem } \\
\text { Pembangkit }\end{array}$} & Beban & $\begin{array}{l}\text { Fuel } \\
\text { Cost }\end{array}$ & COE & NPC & $\begin{array}{l}\text { Ops. } \\
\text { Cost }\end{array}$ & $\begin{array}{l}\text { Initial } \\
\text { Capital }\end{array}$ \\
\hline & & $\begin{array}{c}\text { kWh/ } \\
\text { hari }\end{array}$ & $\%(C O E)$ & \$/kWh & $\begin{array}{c}\$ \\
\text { (Juta) }\end{array}$ & \$/tahun & $\$$ \\
\hline I & $\begin{array}{l}\text { SVO }(360 \mathrm{~kW})+ \\
\text { Biogas }(360 \mathrm{~kW})\end{array}$ & 4000 & 56 & 0,437 & 9,21 & 601.719 & 525.871 \\
\hline II & $\begin{array}{l}\text { SVO }(360 \mathrm{~kW})+ \\
\text { Biogas }(360 \mathrm{~kW})\end{array}$ & 4000 & 40 & 0,310 & 6,53 & 416.211 & 525.871 \\
\hline
\end{tabular}

Simulasi menghasilkan operasi sistem PLH skenario I dengan nilai NPC yang lebih tinggi dari skenario II. Demikian pula dengan nilai COE dan nilai operation cost, operasi skenario I menghasilkan nilai lebih tinggi dari operasi skenario II. Hasil ini menunjukkan bahwa biaya bahan bakar untuk operasi skenario I lebih tinggi dari operasi skenario II. Hal ini terjadi karena skenario I menghasilkan kerugian berupa pemborosan bahan bakar dari excess electricity yang terjadi.

HPP listrik yang dihasilkan dari operasi skenario I maupun skenario II lebih tinggi dari HPP standar acuan, tetapi menghasilkan biaya bahan bakar (\% COE) lebih rendah dari acuan untuk operasi skenario I maupun skenario II. Hal ini menunjukkan bahwa pemakaian bahan bakar dari sumber lokal dapat membantu mengurangi HPP listrik.

\subsubsection{Analisis Faktor GRK Sistem Pembangkit Listrik}

Dalam kajian ini, sebagai batasan standar emisi $\mathrm{CO}_{2}$ maksimum yang dipersyaratkan untuk operasi sistem pembangkit mengacu pada baseline faktor emisi gas rumah kaca (GRK) ratarata PLTD di PLN Sumbawa sebesar 0,628 kg/kWh. Sementara itu, standar pembakaran mengacu pada perbandingan campuran bahan bakar-udara $\approx 1 / 14,7$ (Usman, 1979). Tabel 6 menampilkan data spesifikasi (faktor GRK) hasil simulasi sistem PLH berdasarkan skenario I dan II.

Tabel 6. Data Spesifikasi (Faktor GRK) Hasil Simulasi

\begin{tabular}{|c|c|c|c|c|c|c|}
\hline \multirow{2}{*}{$\begin{array}{l}\text { Skena } \\
\text { rio }\end{array}$} & \multirow{2}{*}{ Sistem Pembangkit } & Beban & $\begin{array}{l}\text { Produksi } \\
\text { Listrik }\end{array}$ & $\begin{array}{l}\text { Produksi } \\
\mathrm{CO}_{2}\end{array}$ & $\mathrm{CO}_{2}$ & $\mathbf{R F}$ \\
\hline & & $\begin{array}{l}\text { kWh/ } \\
\text { hari }\end{array}$ & kWh/tahun & Kg/tahun & kg/kWh & $\%$ \\
\hline I & $\begin{array}{l}\text { SVO }(360 \mathrm{~kW})+\text { Biogas } \\
(360 \mathrm{~kW})\end{array}$ & 4000 & 3.319 .560 & 177.120 & 0,053 & 88,6 \\
\hline II & $\begin{array}{l}\text { SVO }(360 \mathrm{~kW})+\text { Biogas } \\
(360 \mathrm{~kW})\end{array}$ & 4000 & 1.460 .000 & 148.790 & 0,102 & 90,3 \\
\hline
\end{tabular}

Simulasi menunjukkan kapasitas sistem PLH dalam operasi skenario I menghasilkan emisi $\mathrm{CO}_{2}(\mathrm{~kg} / \mathrm{kWh})$ yang lebih rendah dibandingkan dengan skenario II. Kondisi ini terjadi karena pada skenario I sistem pembangkit utama beroperasi pada kapasitas $100 \%$ dan menghasilkan output listrik (kWh/hari) yang lebih tinggi. Selain itu, spesifikasi standar dan karakteristik gas engine pada umumnya menghasilkan emisi gas buang yang rendah dibandingkan engine berbahan bakar minyak untuk kapasitas daya yang sama. Genset berbahan bakar gas menghasilkan nilai emisi $\mathrm{CO}_{2}(\mathrm{~kg} / \mathrm{kWh})$ yang lebih rendah dibandingkan dengan genset berbahan bakar minyak sehingga emisi GRK yang dihasilkan operasi ini menjadi lebih rendah dari baseline faktor emisi GRK rata-rata PLTD di PLN Sumbawa yang berbahan bakar minyak solar. Renewable fraction (RF) dari operasi skenario I lebih rendah 
dari skenario II karena pada skenario I genset SVO beroperasi dengan capacity factor yang lebih besar dibandingkan dengan skenario II. Dimana, operasi genset berbahan bakar minyak menghasilkan emisi GRK yang lebih tinggi daripada operasi genset berbahan bakar gas.

\subsection{Solusi dan Rekomendasi Untuk Optimalisasi Sistem PLH}

Hasil simulasi operasi sistem PLH yang paling sesuai dengan kriteria optimalisasi berdasarkan faktor teknis dan faktor emisi GRK adalah operasi skenario I. Kendala dan kekurangan operasi skenario I yang belum optimal adalah masih tingginya nilai NPC dan nilai COE karena excess electricity yang tinggi dan menimbulkan kerugian bahan bakar yang besar. Oleh karenanya perlu dilakukan penambahan beban sesuai produksi listrik yang dihasilkan pembangkit. Langkah optimalisasi yang dilakukan adalah menambah sistem energy storage berupa baterai dan sistem inverter-rectifier seperti pada Tabel 7. Adapun harga baterai dan harga inverter yang digunakan diperlihatkan pada Tabel 8.

Tabel 7. Spesifikasi Baterai dan Inverter

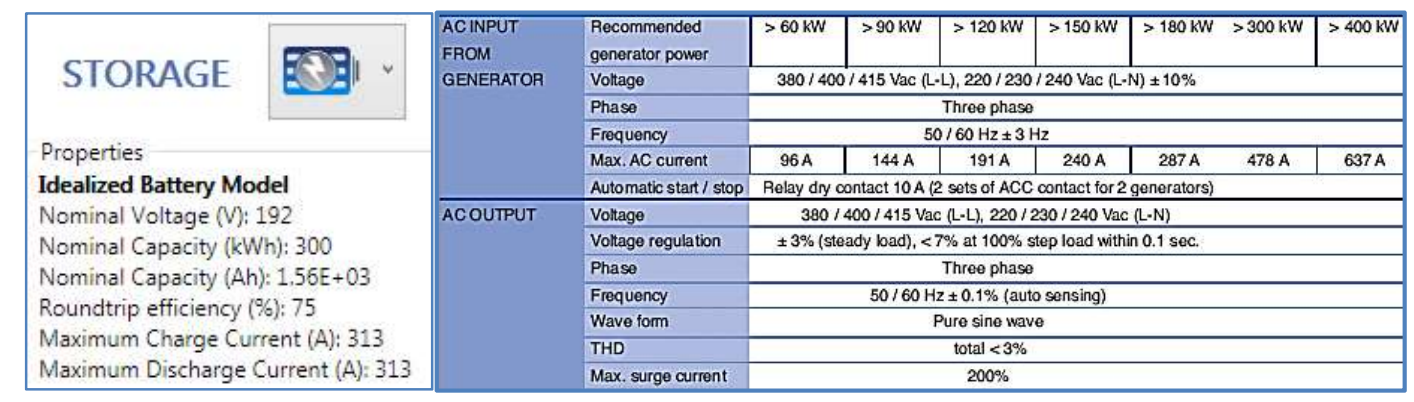

Tabel 8. Harga Baterai dan Harga Inverter

\begin{tabular}{|c|c|c|c|c|c|c|c|c|c|c|c|}
\hline \multirow{3}{*}{$\begin{array}{l}\text { Batteries } \\
\text { Quantity }\end{array}$} & \multirow{3}{*}{\begin{tabular}{|c} 
Capital \\
(5) \\
$90,000.00$ \\
\end{tabular}} & \multirow{2}{*}{\multicolumn{2}{|c|}{$\begin{array}{l}\text { Replacement } \\
\text { (S) }\end{array}$}} & \multirow{2}{*}{\multicolumn{2}{|c|}{$\begin{array}{c}\text { O\&M } \\
\text { (S/year) }\end{array}$}} & & \multirow{3}{*}{$\begin{array}{l}\text { Name: } \\
\text { Abbrevistion: }\end{array}$} & \multicolumn{4}{|c|}{ Leonics MTP. $4117 \mathrm{H} 300 \mathrm{kV}$} \\
\hline & & & & & & & & \multirow{2}{*}{\multicolumn{4}{|c|}{ Leon30 }} \\
\hline & & & & & $1,000.00$ & & & & & & \\
\hline \multirow[t]{3}{*}{ Lifetime } & & & & \multirow{3}{*}{\multicolumn{2}{|c|}{ (190) }} & More... & Costs - & & & & \\
\hline & \multirow{2}{*}{\multicolumn{2}{|c|}{$\begin{array}{l}\text { time (yesrs): } \\
\text { throughput (kWh): }\end{array}$}} & 25.00 & & & & Copscity (kW) & $\begin{array}{c}\text { Copital } \\
\text { (s) }\end{array}$ & $\begin{array}{c}\text { Replacement } \\
\text { (s) }\end{array}$ & $\begin{array}{c}\text { O\&M } \\
\text { (S/yest) }\end{array}$ & \\
\hline & & & $876,000.00$ & & & & 1 & 5600.00 & 5600.00 & $\$ 100.00$ & $x$ \\
\hline
\end{tabular}

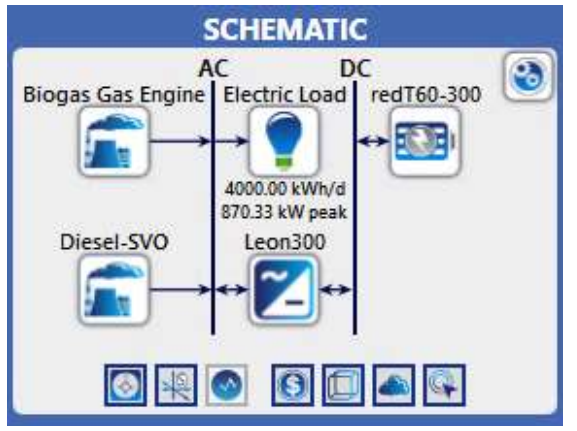

Gambar 8. Arsitektur Mikrogrid Sistem PLH

Arsitektur hasil optimalisasi berdasarkan faktor teknis, faktor ekonomi dan faktor emisi GRK operasi pembangkit skenario I dengan penambahan energy storage diperlihatkan pada Gambar 8. Adapaun hasil optimalisasi operasi sistem PLH yang direkomendasikan diperlihatkan pada Tabel 9. 
Tabel 9. Data Spesifikasi Sistem Microgrid Hasil Operasi - Skenario I

\begin{tabular}{|c|c|c|c|c|c|c|c|c|c|c|c|c|c|c|c|}
\hline \multirow{3}{*}{ Sken. } & \multirow{2}{*}{ Load } & \multirow{2}{*}{ Sistem } & \multicolumn{3}{|c|}{ Energy Storage } & \multicolumn{4}{|c|}{ Faktor Teknis } & \multicolumn{4}{|c|}{ Faktor Ekonomi } & \multicolumn{2}{|c|}{$\begin{array}{c}\text { Faktor } \\
\text { Emisi GRK }\end{array}$} \\
\hline & & & Bat. & Invrt & Rectif & $\begin{array}{c}\text { Electr } \\
\text { Product }\end{array}$ & $\begin{array}{l}\text { Fuel } \\
\text { Cons. }\end{array}$ & $\begin{array}{c}\text { Exc } \\
\text { Elect. }\end{array}$ & $C F$ & COE & NPC & $\begin{array}{c}\text { Int } \\
\text { Capt }\end{array}$ & $\begin{array}{l}\text { Fuel } \\
\text { Cost }\end{array}$ & $\mathrm{CO}_{2}$ & RF \\
\hline & $\begin{array}{c}\text { kWh/ } \\
\text { hari }\end{array}$ & kW & $\begin{array}{c}\text { Unit } \\
\text { (kWh) }\end{array}$ & $\begin{array}{l}\text { Unit } \\
\text { (kW) }\end{array}$ & $\begin{array}{l}\text { Unit } \\
\text { (kW) }\end{array}$ & kWh/tahun & tahun $^{-1}$ & \multicolumn{2}{|c|}{$\%$} & $\$ / \mathbf{k W h}$ & $\begin{array}{c}\$ \\
\text { (Juta) }\end{array}$ & $\$$ & $\begin{array}{c}\% \\
\text { COE }\end{array}$ & $\begin{array}{c}\mathbf{k g} / \\
\mathbf{k W h}\end{array}$ & $\%$ \\
\hline \multirow{2}{*}{ I } & \multirow{2}{*}{4.000} & Biogas & \multirow{2}{*}{ none } & \multirow{2}{*}{ none } & \multirow{2}{*}{ none } & 3.153 .240 & 9.083 ton & \multirow{2}{*}{56} & 100 & \multirow{2}{*}{0,437} & \multirow{2}{*}{9,21} & \multirow{2}{*}{525.871} & \multirow{2}{*}{56} & \multirow{2}{*}{0,053} & \multirow{2}{*}{88,6} \\
\hline & & SVO & & & & 166.320 & $56.268 \mathrm{ltr}$ & & 5,27 & & & & & & \\
\hline \multirow{2}{*}{$\begin{array}{c}\text { Mikro } \\
\text { grid }\end{array}$} & \multirow{2}{*}{4.000} & Biogas & \multirow{2}{*}{$3 \times 300$} & \multirow{2}{*}{$1 \times 157$} & \multirow{2}{*}{$1 \times 125$} & 1.859 .040 & 5.355 ton & \multirow{2}{*}{14,5} & 58,9 & \multirow{2}{*}{0,368} & \multirow{2}{*}{7,75} & \multirow{2}{*}{889.806} & \multirow{2}{*}{36} & \multirow{2}{*}{0,016} & \multirow{2}{*}{98,2} \\
\hline & & SVO & & & & 25.560 & $8.647 \mathrm{Itr}$ & & 0,81 & & & & & & \\
\hline
\end{tabular}

\subsubsection{Faktor Teknis Sistem PLH genset Biogas+genset SVO Hasil Optimalisasi}

Genset Biogas beroperasi dengan capacity factor 58,9\% menghasilkan mean electrical efficiency $29,1 \%$ dan specific fuel consumption $0,951 \mathrm{~kg} / \mathrm{kWh}$. Sistem ini menghasilkan electrical production sebesar 1,859,040 kWh/tahun dan membutuhkan bahan bakar sebesar 5.355 ton/tahun untuk beroperasi 5.164 jam/tahun dengan umur operasi 3,87 tahun. Gambar 9 menampilkan grafik output genset biogas.

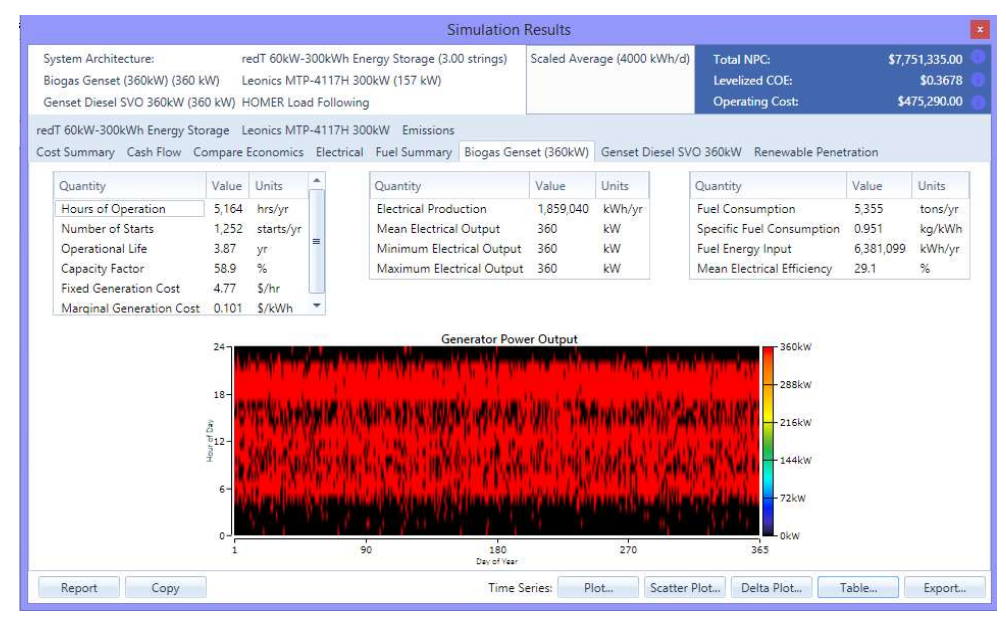

Gambar 9. Grafik Output Genset Biogas

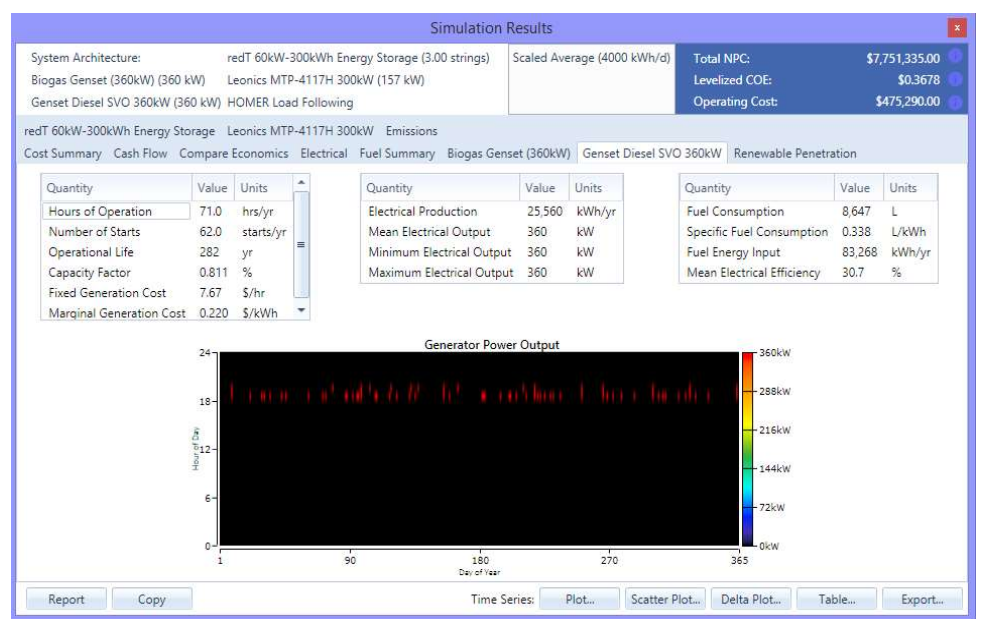

Gambar 10. Grafik Output Genset SVO dan Konsumsi Bahan Bakar SVO

Sementara itu, genset SVO beroperasi dengan capacity factor $0,81 \%$ menghasilkan mean electrical efficiency $30,7 \%$ serta specific fuel consumption sebesar 0,338 liter/kWh. Sistem ini menghasilkan electrical production sebesar $25.560 \mathrm{kWh} /$ tahun dan membutuhkan bahan 
bakar sebesar 8.647 liter/tahun untuk beroperasi 71 jam/tahun dengan umur operasi 282 tahun. Gambar 10 menampilkan grafik output genset SVO dan pemakaian bahan bakar SVO.

Operasi ini menghasilkan listrik total sebesar $1.460 .000 \mathrm{kWh} /$ tahun dengan excess electricity sebesar 14,5\% (273.249 kWh/tahun). Produksi listrik dari genset Biogas sebesar 98,6\% dan sisanya $1,36 \%$ diperoleh dari genset SVO. Genset SVO hanya beroperasi pada beban puncak saja. Gambar 11 menampilkan grafik produksi listrik sistem PLH.

\subsubsection{Faktor Ekonomi Sistem PLH genset Biogas+genset SVO Hasil Optimalisasi}

Untuk masa operasi 25 tahun, tambahan biaya untuk operasi sistem baterai sebesar $\$ 724,483.94$ dan operasi sistem inverter-rectifier sebesar $\$ 401,308.91$. Biaya ini sudah termasuk initial capital ( $11 \%$ dari nilai NPC), replacement (10\% dari nilai NPC), O\&M (43\% dari nilai NPC), fuel cost (36\% dari nilai NPC) dan salvage (-1\% dari nilai NPC) di akhir proyek. Fuel cost SVO sebesar $6 \%$ dan $50 \%$ bahan baku bungkil minyak.

Pada sistem ini terdapat $3 \times 300 \mathrm{~kW}$ baterai dan 1 unit sistem inverter-rectifier. Initial capital untuk pengadaan baterai adalah $\$ 246,857$ dan untuk pengadan inverter-rectifier adalah $\$ 93,935$. Operasi mikrogrid sistem PLH ini menghasilkan cost of energy (COE) sebesar $\$ 0,368 / \mathrm{kWh}$ dan total net present cost (NPC) $\$ 7.750 .000$ untuk 25 tahun.

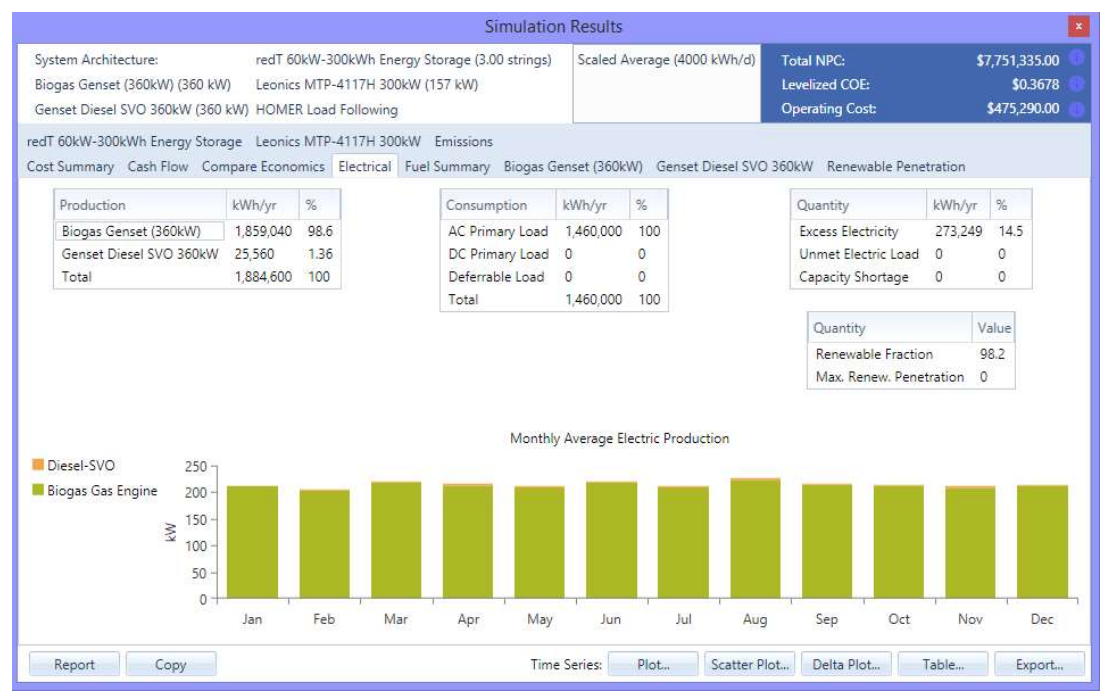

Gambar 11. Produksi Listrik Sistem PLH

\subsubsection{Faktor Emisi GRK Sistem PLH genset Biogas+genset SVO Hasil Optimalisasi}

Berdasarkan hasil simulasi, sistem PLH dalam operasi ini menghasilkan emisi $\mathrm{CO}_{2}$ lebih rendah $0,037 \mathrm{~kg} / \mathrm{kWh}$ dari skenario I. Ini terjadi karena pada skenario ini genset biogas beroperasi menghasilkan listrik (kWh/hari) proporsional. Genset biogas beroperasi dengan capacity factor yang lebih rendah dari skenario I tetapi menghasilkan efisiensi termal dan efisiensi elektrik yang sama dengan hasil skenario I. Skenario ini beroperasi menghasilkan renewable fraction lebih besar dari 9,6\%. Hal ini terjadi karena sistem genset biogas beroperasi $98,6 \%$ menghasilkan listrik dari total produksi. 


\section{KESIMPULAN}

Beberapa kesimpulan penting dapat diikhtisarkan sebagai berikut:

1. Mikrogrid berbasis sistem PLH (genset SVO dan genset Biogas) jarak pagar dapat mengatasi kendala pelayanan kebutuhan listrik yang kurang optimal di lokasi kajian.

2. Operasi sistem PLH skenario I (operasi daya maksimal untuk $1 X 360 \mathrm{~kW}$ genset SVO + $1 X 360 \mathrm{~kW}$ genset Biogas) menghasilkan excess electricity dan menimbulkan kerugian bahan bakar.

3. Operasi sistem PLH skenario II (Operasi Daya Proporsional sesuai Beban untuk 1 X360 kW genset SVO $+1 \times 360 \mathrm{~kW}$ genset Biogas) tanpa excess electricity tetapi efisiensi termal rendah dan emisi gas buang tinggi serta capacity factor rendah.

4. Penambahan sistem energy storage dapat memperbaiki faktor teknis, faktor ekonomi dan faktor emisi gas buang genset.

5. Sistem mikrogrid berbasis PLH jarak pagar yang optimal menghasilkan average load scale $4.000 \mathrm{kWh} / \mathrm{hari}$ dengan excess electricity $14,5 \%$

6. Sistem mikrogrid berbasis PLH jarak pagar yang optimal terdiri dari $1 \times 360 \mathrm{~kW}$ genset SVO + 1X360 kW genset Biogas + Baterai 300 kWh + inverter-rectifier $300 \mathrm{~kW}$.

7. Genset biogas membutuhkan $2,7 \mathrm{~kg}$ bungkil minyak jarak pagar untuk membangkitkan 1 kWh listrik.

8. Genset SVO membutuhkan 0,3 liter minyak jarak pagar murni (SVO) untuk membangkitkan 1 kWh listrik.

9. 1 ha kebun jarak pagar dapat menghasilkan listrik $19.425 \mathrm{kWh} /$ tahun dari genset SVO ditambah dengan produksi listrik sebesar $6.475 \mathrm{kWh} /$ tahun dari genset biogas.

10. Operasi mikrogrid berbasis sistem PLH genset biogas dan genset SVO menghasilkan emisi GRK 0,016 kg/kWh lebih kecil dari baseline PLN Sumbawa.

11. Operasi mikrogrid berbasis sistem PLH genset biogas dan genset SVO ini menghasilkan nilai COE $\$ 0,368 / \mathrm{kWh}$ dan Net Present Cost (25 tahun operasi) sebesar $\$ 7.750 .000$.

12. Biaya bahan bakar sebesar $36 \%$ nilai total COE dan lebih rendah dari standar normal.

\section{DAFTAR RUJUKAN}

BPS Kabupaten Sumbawa. (2016). Kabupaten Sumbawa Dalam Angka. Sumbawa: BPS Sumbawa.

Direktorat PPK. (2012). Dipetik Januari 02, 2018, dari www.ppk-kp3k.kkp.go.id: http://www.ppk-kp3k.kkp.go.id/direktori-pulau/index.php/public_c/pulau_info/5018

ESDM. (2017). Ongkos Produksi Listrik Indonesia Timur 2017. Dipetik Januari 21, 2018, dari https://www.cnbcindonesia.com/news/20180322143125-4-8163/-naik-jadi-rp-1025per-kwh

Google Earth. (2018). Dipetik Januari 25, 2018, dari https://www.google.com/maps/@$8.13979,117.39102,12414 \mathrm{~m} /$ data $=! 3 \mathrm{~m} 1 ! 1 \mathrm{e} 3$

Goldemberg, J. (1990). Energy for the Developing World. Scientific American, 263 (3), 110-118. 
Gunawan. (2016). Model Pembangkitan Listrik Hibrid PV-Genset Berbasis Komunal di Pulau Karimun Jawa. Simposium Nasional RAPI XV-2016 FT UMS. (pp. 442 - 449).

HOMER Energy. (2015). Dipetik Februari 2017, dari https://www.homerenergy.com/products/pro/index.html.

Ibrahim, \& Rusirawan. (2017). Design and Optimization of Hybrid Power Plant in Household Scales using Homer Models. The 1st Faculty of Industrial Technology International Congress 2017. (pp. 1 - 8).

Irawati, R., \& Zuhaidi. (2012). Analisa Pembangkit Listrik Tenaga Hibrida untuk Pemenuhan Kebutuhan Energi Listrik di Pulau Pramuka. Jurnal Ketenagalistrikan dan Energi Terbarukan, $11(02), 81$ - 92.

Kementerian ESDM. (2016). Pengesahan RUPTL PT. PLN 2016-2025. KepMen ESDM 5899 K/20/MEM/2016. Jakarta, Indonesia: Kementerian ESDM.

Nababan, T. S. (2015). Household Characteristics that Influence Simple Household Demand on Electricity. Jurnal Ekonomi Pembangunan ISSN 1411-6081, 16(1), 61-74.

Paudel, S. (2013). Technical and Economic Assessment of Renewable Energy Sources for Telecom Application: A Case Study of Nepal Telecom. The 5th International Conference on Power and Energy Systems (pp. 1-11). Kathmandu: Eindhoven University of Technology.

PLN Sumbawa. (2016). Elektrifikasi PLN di Pulau Medang Nusa Tenggara Barat. Sumbawa Besar: PLN Sumbawa.

Suárez, C. (1995). Energy Needs for Sustainable Human Development (114 p). (Josoldemberg, \& T. B. Johansson, Penyunt.) New York, United State of America: United Nations Development Programme.

Usman. (1979). Motor Bakar 3. Jakarta: Direktorat Pendidikan Menengah Kejuruan, Departemen Pendidikan dan Kebudayaan.

Wiyono, G., \& Tatipikalawan, P. S. (2015). Evaluasi dan Perencanaan Pengembangan Sistem Jaringan Listrik Kampus Politeknik Negeri Ambon. Jurnal EECCIS, 9 (1).

Yunus, S. (2013). Economic Study of Hibrid Power System in Selayar Island. International Workshop on Modern Research Methods in Electrical Engineering. (pp.1 - 4). 